\title{
COMBINING ABILITY FOR NITROGEN USE IN A SELECTED SET OF INBRED LINES FROM ATROPICAL MAIZE POPULATION
}

\author{
ELTO EUGENIO GOMES E GAMA ${ }^{1}$, IVANILDO EVODIO MARRIEL ${ }^{1}$, PAULO EVARISTO DE \\ OLIVEIRA GUIMARÃES ${ }^{1}$, SIDNEY NETTO PARENTONI ${ }^{1}$, MANOEL XAVIER DOS SANTOS ${ }^{1}$, \\ CLESO ANTONIO PATTO PACHECO ${ }^{1}$, WALTER FERNANDES MEIRELES ${ }^{1}$, PEDRO HELIO \\ ESTEVÃO RIBEIRO ${ }^{1}$, ANTÔNIO CARLOS DE OLIVEIRA ${ }^{1}$
}

\begin{abstract}
${ }^{1}$ Pesquisadores, Embrapa Milho e Sorgo. Caixa Postal 151, CEP, 35701-970 Sete Lagoas, MG. E-mail: gamaelto@cnpms.embrapa.br (autor para correspondência).
\end{abstract}

Revista Brasileira de Milho e Sorgo, v.1, n.3, p.68-77, 2002

\begin{abstract}
Tolerance rather than resistance, is the crop response mechanism sought by maize breeders for cultivation under low levels of nitrogen. Although improved nitrogen use is in intensive research by maize breeders, little is known about its inheritance on tropical maize germplasm. The objectives of this study were to evaluate the $\mathrm{N}$ use through yield and other traits, and to determine the importance of general (GCA) and specific (SCA) combining ability effects in the inheritance of $\mathrm{N}$ use, for yield, using a diallel of crosses among a selected set of tropical maize lines under two levels of $\mathrm{N}$. A comparison of relative magnitudes of GCA and SCA for ear yield (EY) suggests that this trait was governed more by dominance than additive gene action, and the contribution of additive genes for nitrogen utilization efficiency decreases under $\mathrm{N}$ nutrient shortage. Since, for this set of lines, only non additive effects were significant for this trait, the lines with favorable SCA could be used as donors of $\mathrm{N}$ use efficiency in a hybrid development program. The line L2 was identified as being the most suitable combining overall parents in this study for improving EY. The crosses L 3 x L 7, L 1 x L 2 and L 7 x L 10 showed to be promising combinations based on the significant SCA effects for lines and hybrids development. The results of this study can enhance the use of promising inbred lines in a program focused on developing hybrid that efficiently can take up and uses nitrogen.
\end{abstract}

Key words: Zea mays L., nitrogen stress, general and specific combining ability, yield.

\section{CAPACIDADE DE COMBINAÇÃO PARA USO DE NITROGÊNIO DE UM GRUPO DE LINHAGENS SELECIONADAS DE UMA POPULAÇÃO DE MILHOTROPICAL.}

RESUMO - Tolerância, em vez de resistência, é um mecanismo de resposta das plantas que tem sido buscado por melhoristas de milho, para cultivos com baixos níveis de nitrogênio. Mesmo com o crescimento das pesquisas por melhoristas, visando o uso mais eficiente do nitrogênio, pouco se conhece sobre sua implicação no comportamento de linhagens e a respeito de sua herdabilidade em germoplasma de milho tropical. Os objetivos deste estudo foram avaliar o uso do nitrogênio, com base na produção de espigas (PE) e de outros caracteres, bem como determinar a importância dos efeitos das capacidades geral (CGC) e específica (CEC) de combinação na herança do uso de nitrogênio, usando-se cruzamento dialelo de um grupo de linhagens selecionadas, em dois níveis de nitrogênio. Uma comparação da magnitude relativa das CGC e CEC para PE sugere que esta característica foi mais controlada por genes 
em dominância que devido à ação gênica aditiva e que a contribuição dos genes aditivos para o uso eficiente de nitrogênio diminuiu com o estresse de nitrogênio. Como, para esse grupo de linhagens, somente os efeitos não aditivos foram significativos nas condições de estresse de $\mathrm{N}$, as linhagens deste estudo com CEC favoráveis poderiam ser usadas como doadoras da tolerância ao estresse de $\mathrm{N}$, em programas de desenvolvimento de híbridos. A linhagem L2 foi identificada como sendo a mais promissora para combinação com as demais linhagens, para se aumentar a PE. Os cruzamentos L3 x L7, L1 x L2 e L7 x L10, baseados nos efeitos da CEC, mostram ser combinações promissoras para um programa de desenvolvimento de linhagens e híbridos. Os resultados deste estudo indicam o potencial a ser explorado com o uso de linhagens promissoras, em programa de melhoramento focado no desenvolvimento de híbridos eficientes na utilização do nitrogênio.

Palavras-chave: Zea mays $L$., estresse de nitrogênio, capacidade geral e específica de combinação, produção.

Brazil produced about 41 million tons of maize in the 2000/2001 harvests, making maize the second most cultivated cereal, with an area of 13.750 million ha (CONAB, 2001) and a mean consumption of $25 \mathrm{~kg} \mathrm{ha}^{-1}$ nitrogen estimated from ANDA (2001)data.

Nitrogen deficiency is one of the most important stresses affecting maize production in tropical areas (Lafitte \& Bänziger, 1995). The great majority of tropical soils present low levels of fertility, consequently higher levels of yields require higher inputs of chemical fertilizers, mainly Nitrogen. Thus, a maize cultivar with genetic potential to use $\mathrm{N}$ efficiently could produce economically in poor soils with low levels of fertilizer applications or high yields with better inputs of fertilizers due to its capacity to utilize N efficiently. Moll et al., (1987) and Pollmer et al.,(1979) pointed out that variation in the capacity of maize genotypes to take up $\mathrm{N}$ from the soil and to utilize plant nitrogen for grain production has been widely reported. Efficient and inefficient maize hybrids respond differently to the nutrient supply in the soil (Parentoni et al. 1998).Genetic variation in response to N supply of inbred line (Balko \& Russel, 1980), has been observed and it appears to be possible to develop hybrids with tolerance to low $\mathrm{N}$ in soils. In most breeding programs one of the main objectives is to identify inbred lines with productive potential "per se" and high combining ability for hybrid production that express high heterotic levels for grain yield. Trials conducted at low yielding environments have a higher frequency of producing statistically nonsignificant differences, or having a larger coefficient of error variation than trials conducted under high yielding environments. This is because the error variance usually does not decrease as much as the genetic variance when going from high to low yielding environments (Bänziger et al., 1997). Despite the environmental and economical limitations related to $\mathrm{N}$ fertilizer utilization, traditionally, the greater majority of the maize breeding programs in the tropics are under optimum fertilization conditions, where heritability and potential selection genetic gains are usually much greater. Maize cultivars present different behavior when grown in low levels of $\mathrm{N}$ and show different $\mathrm{N}$ partition and biomass inside the plant, especially in terms of $\mathrm{N}$ removed from the vegetative tissues (Ta \& Wieland, 1992). Nitrogen affects cell and tissue growth, thereby influencing leaf area and photosynthetic capacity (Pan et al., 1985 and Settini \& Maranville, 1998).

Some morphological and physiological responses of maize when in $\mathrm{N}$ deficiency conditions are shown through low plant height, low efficiency in 
light interception, accelerate senescence, increment in $\mathrm{N}$ mobilization to grain and reduction in $\mathrm{N}$ concentration in the plant (Muchow \& Davis, 1988). With respect to genetics parameters related to $\mathrm{N}$ use efficiency, dominance effects had the great contribution to the observed genetic variance (Clark $\&$ Duncan, 1991). The genetic variation due to the general combining ability was greatly related to $\mathrm{N}$ plant structure (productivity and dry matter), indicating that differences among crosses could be attributed to additive gene effects (Rizzi et al., 1993). The objectives of this work were to evaluate the $\mathrm{N}$ use efficiency of inbred lines and determine the relative importance of general and specific combining ability for $\mathrm{N}$ efficiency by using diallel crosses.

\section{Material and Methods}

A selected group of ten tropical inbred lines of maize derived from a tropical yellow dent tuxpeño synthetic population (CMS 61) was crossed in a diallel system through controlled hand pollination. The resulting 45 single crosses, the 10 parental lines and a control - $\mathrm{N}$ use efficient line, were grown in the experimental area of Embrapa Milho e Sorgo, in Sete Lagoas, MG, in 2000. For both trials was used a lattice design $7 \times 8$ with two replications, and plot size was a single $5 \mathrm{~m}$ row spacing $0,90 \times 0,20 \mathrm{~m}$ between and within rows, respectively. Each of the two nitrogen levels was considered a separate field trial plant adjacent to each other in a Latosoil darkred, dystrophic and of clay texture, typical of the Brazilian savannas central areas, with low levels of $\mathrm{N}$. The first area, with $\mathrm{N}$ stress $\left(\mathrm{N} 0=10 \mathrm{~kg} \mathrm{ha}^{-1}\right.$ of $\mathrm{N}$ ), was planted using $250 \mathrm{~kg} \mathrm{ha}^{-1}$ of the formula 4:14:8 plus $\mathrm{Zn}$ and $20 \mathrm{~kg} \mathrm{ha}^{-1}$ of FTE BR 12 (micronutrient source). The second area, with no $\mathrm{N}$ stress $\left(\mathrm{N} 1=120 \mathrm{~kg} \mathrm{ha}^{-1}\right.$ of N) was used $250 \mathrm{~kg} \mathrm{ha}^{-1}$ of the formula 4:14:8 plus Zn, $20 \mathrm{~kg}$ of FTE BR 12 (micronutrient source) and $30 \mathrm{~kg} \mathrm{ha}^{-1}$ of $\mathrm{N}$. At the latter, five weeks after sowing, $90 \mathrm{~kg} \mathrm{ha}^{-1}$ of N(Urea) was side dressed applied. Data were collected for ear yield (EY), plant height $(\mathrm{PH})$, ear height $(\mathrm{EH})$, number of root and stalk lodge (NRSL), and prolificacy (Prol). Each experiment was analyzed separately as a lattice design. For evaluation of the genotype performance there were imposed two criteria: a) yield in the environment under $\mathrm{N}$ stress, and $b$ ) relative performance in the environments under no and with $\mathrm{N}$ stress. This performance was evaluated using a $\mathrm{N}$ stress index defined as: $\mathrm{NSI}=$ $\left(\mathrm{Y}_{N 1}-\mathrm{Y}_{N 0}\right) /\left(\mathrm{Y}_{\bar{M}}-\mathrm{Y}_{\bar{M}}\right)$. Where: $\mathrm{Y}_{N 1}$ and $\mathrm{Y}_{N 0}$ are productions under no stress $(\mathrm{N} 1)$ and with stress (N0); $\mathrm{Y}_{\bar{M}}$ and $\mathrm{Y}_{\bar{M}}$ are mean productions, considering all genotypes, under $\mathrm{N} 0$ and $\mathrm{N} 1$ environments, respectively. Low values for NSI indicate better genotype tolerance to $\mathrm{N}$ stress. Values around 1,0 indicate median tolerance, and high values are associated with low tolerance to $\mathrm{N}$ stress. Thus, a high standing genotype for $\mathrm{N}$ tolerance is the one that yields above the general mean under low level of $\mathrm{N}$ and with NSI value less than one $(\mathrm{NSI}<1,0)$. Also date for EY were analyzed using Griffing's Model I, Method 2 (Griffing, 1956) to calculate general and specific combining ability.

\section{Results and Discussion}

Nitrogen absorption played an important role in confirming that $\mathrm{N}$ stress was a major factor in creating differences in the studied traits between the environments. The use of fields that has been previously depleted of $\mathrm{N}$ result in a severe $\mathrm{N}$ stress in the low $\mathrm{N}$ level experiment.

Nitrogen treatment had a significant effect on ear yield (EY), plant height $(\mathrm{PH})$, ear height $(\mathrm{EH})$, and prolificacy (Prol) traits (Table 1).Yield reduction under low nitrogen level (N0) in comparison to higher nitrogen level (N1) treatments, in terms of average EY, ranged from $1206 \mathrm{~kg} \mathrm{ha}^{-1}$ to $2080 \mathrm{~kg} \mathrm{ha}^{-1}$ for lines and from $4346 \mathrm{~kg} \mathrm{ha}^{-1}$ to $6730 \mathrm{~kg} \mathrm{ha}^{-1}$ for the crosses. One of the main effects of $\mathrm{N}$ stress is a 
TABLE 1. Means for ear yield (EY), plant height (PH), ear height (EH) number of root and stalk lodge (NRSL) and prolificacy (Prol) for 10 inbred lines and the diallel set of crosses among these lines grown in two levels of N.

\begin{tabular}{|c|c|c|c|c|c|c|c|c|c|c|c|c|}
\hline \multirow{2}{*}{ Trat. } & \multicolumn{2}{|c|}{$E Y\left(\mathrm{~kg} \mathrm{ha}^{-1}\right)$} & \multicolumn{2}{|c|}{$\mathrm{PH}(\mathrm{cm})$} & \multicolumn{2}{|c|}{$\mathbf{E H}(\mathrm{cm})$} & \multicolumn{2}{|c|}{ NRSL } & \multicolumn{2}{|c|}{ St } & \multicolumn{2}{|c|}{ Prol } \\
\hline & N1 & No & N1 & No & N1 & No & N1 & No & N1 & No & N1 & No \\
\hline L1 & 2164 & 884 & 145 & 135 & 85 & 68 & 2 & 0 & 13 & 15 & 1,04 & 0,89 \\
\hline L2 & 2545 & 2782 & 163 & 133 & 88 & 70 & 0 & 0 & 15 & 16 & 1,36 & 1,20 \\
\hline L3 & 1614 & 251 & 155 & 105 & 78 & 43 & 0 & 1 & 16 & 18 & 1,03 & 0,35 \\
\hline L4 & 1173 & 679 & 158 & 140 & 85 & 68 & 2 & 0 & 17 & 18 & 0,88 & 0,58 \\
\hline L5 & 2121 & 1628 & 155 & 138 & 98 & 73 & 1 & 0 & 16 & 17 & 0,89 & 1,00 \\
\hline L6 & 2423 & 1460 & 160 & 138 & 88 & 65 & 0 & 0 & 16 & 17 & 1,02 & 0,80 \\
\hline L7 & 2615 & 834 & 180 & 125 & 95 & 60 & 0 & 1 & 15 & 16 & 1,07 & 0,75 \\
\hline L8 & 2797 & 1384 & 173 & 135 & 98 & 73 & 1 & 1 & 12 & 15 & 1,26 & 0,81 \\
\hline L9 & 2129 & 1025 & 183 & 150 & 98 & 73 & 0 & 1 & 14 & 14 & 1,18 & 0,69 \\
\hline L10 & 1220 & 1133 & 170 & 135 & 98 & 68 & 4 & 2 & 19 & 19 & 0,74 & 0,49 \\
\hline HSI & 9432 & 6619 & 203 & 185 & 105 & 93 & 0 & 3 & 20 & 17 & 1,26 & 1,09 \\
\hline HS2 & 6213 & 4585 & 210 & 190 & 115 & 95 & 1 & 6 & 17 & 18 & 1,03 & 0,94 \\
\hline HS3 & 8091 & 4380 & 208 & 190 & 135 & 105 & 2 & 7 & 19 & 20 & 1,53 & 1,21 \\
\hline HS4 & 5623 & 3638 & 208 & 158 & 113 & 83 & 1 & 1 & 17 & 17 & 1,25 & 1,00 \\
\hline HS5 & 7399 & 4536 & 218 & 190 & 138 & 90 & 0 & 1 & 13 & 18 & 1,63 & 0,94 \\
\hline HS6 & 8386 & 4536 & 223 & 183 & 130 & 88 & 0 & 0 & 18 & 19 & 1,53 & 0,94 \\
\hline HS7 & 7058 & 3962 & 205 & 173 & 113 & 85 & 2 & 2 & 15 & 20 & 1,37 & 0,98 \\
\hline HS8 & 6902 & 3586 & 213 & 180 & 128 & 105 & 1 & 6 & 19 & 18 & 1,29 & 0,97 \\
\hline HS9 & 7739 & 4972 & 213 & 188 & 118 & 95 & 2 & 5 & 18 & 20 & 1,39 & 1,05 \\
\hline HS 10 & 6456 & 4051 & 218 & 193 & 115 & 98 & 2 & 1 & 13 & 18 & 1,48 & 0,87 \\
\hline HS11 & 7080 & 4465 & 195 & 173 & 108 & 70 & 1 & 1 & 16 & 17 & 1,32 & 1,07 \\
\hline HS 12 & 6196 & 3911 & 215 & 188 & 115 & 90 & 0 & 1 & 17 & 18 & 1,17 & 0,91 \\
\hline HS 13 & 6480 & 4506 & 210 & 193 & 125 & 93 & 1 & 2 & 16 & 18 & 1,25 & 1,00 \\
\hline HS14 & 6840 & 4488 & 223 & 190 & 123 & 78 & 1 & 1 & 20 & 19 & 1,08 & 1,03 \\
\hline HS 15 & 7586 & 4450 & 203 & 183 & 115 & 88 & 0 & 2 & 18 & 19 & 1,31 & 1,00 \\
\hline HS 16 & 6504 & 3330 & 213 & 195 & 128 & 98 & 0 & 0 & 7 & 5 & 1,48 & 1,30 \\
\hline HS 17 & 8545 & 4991 & 218 & 213 & 133 & 118 & 0 & 1 & 22 & 16 & 1,20 & 1,05 \\
\hline HS18 & 6105 & 3828 & 193 & 160 & 120 & 85 & 0 & 1 & 17 & 18 & 1,15 & 0,97 \\
\hline HS 19 & 6581 & 4938 & 210 & 188 & 110 & 95 & 0 & 2 & 16 & 16 & 1,07 & 1,03 \\
\hline $\mathrm{HS} 20$ & 6761 & 5093 & 218 & 190 & 130 & 98 & 1 & 3 & 17 & 18 & 1,39 & 1,06 \\
\hline HS 21 & 5267 & 6395 & 208 & 195 & 118 & 90 & 1 & 1 & 15 & 19 & 1,17 & 1,11 \\
\hline HS 22 & 6413 & 4112 & 205 & 185 & 113 & 100 & 2 & 2 & 16 & 17 & 1,46 & 0,88 \\
\hline $\mathrm{HS} 23$ & 6774 & 4404 & 205 & 183 & 115 & 93 & 6 & 3 & 19 & 19 & 1,13 & 0,89 \\
\hline HS24 & 6909 & 4441 & 198 & 188 & 108 & 105 & 0 & 2 & 18 & 17 & 1,46 & 1,00 \\
\hline HS 25 & 4727 & 3061 & 193 & 158 & 105 & 78 & 1 & 0 & 19 & 15 & 1,08 & 1,00 \\
\hline HS26 & 7486 & 5004 & 215 & 173 & 133 & 100 & 3 & 0 & 18 & 18 & 1,13 & 1,00 \\
\hline $\mathrm{HS} 27$ & 5416 & 2652 & 208 & 160 & 123 & 88 & 1 & 0 & 16 & 17 & 1,41 & 0,80 \\
\hline
\end{tabular}


Gama et al.

Continuação da Tabela 1.

\begin{tabular}{|c|c|c|c|c|c|c|c|c|c|c|c|c|}
\hline \multirow{2}{*}{ Trat. } & \multicolumn{2}{|c|}{$E Y\left(\mathrm{~kg} \mathrm{ha}^{-1}\right)$} & \multicolumn{2}{|c|}{$\mathrm{PH}(\mathrm{cm})$} & \multicolumn{2}{|c|}{$\mathrm{EH}(\mathrm{cm})$} & \multicolumn{2}{|c|}{ NRSL } & \multicolumn{2}{|c|}{ St } & \multicolumn{2}{|c|}{ Prol } \\
\hline & N1 & No & N1 & No & N1 & No & N1 & No & N1 & No & N1 & No \\
\hline HS28 & 6227 & 4150 & 205 & 170 & 125 & 90 & 0 & 0 & 15 & 19 & 1,57 & 1,05 \\
\hline HS29 & 6547 & 3941 & 210 & 180 & 123 & 100 & 0 & 1 & 18 & 19 & 1,14 & 1,00 \\
\hline HS30 & 7606 & 3917 & 208 & 183 & 133 & 100 & 0 & 3 & 18 & 19 & 1,25 & 1,03 \\
\hline HS31 & 5904 & 4349 & 215 & 190 & 120 & 108 & 0 & 0 & 17 & 17 & 1,11 & 0,94 \\
\hline HS32 & 6971 & 4069 & 200 & 183 & 110 & 85 & 0 & 0 & 17 & 22 & 1,07 & 0,91 \\
\hline HS33 & 5998 & 3589 & 208 & 180 & 123 & 125 & 1 & 0 & 17 & 19 & 1,24 & 0,95 \\
\hline HS34 & 5171 & 4575 & 200 & 195 & 120 & 105 & 2 & 1 & 16 & 20 & 1,19 & 0,92 \\
\hline HS35 & 7420 & 5009 & 208 & 188 & 120 & 105 & 1 & 0 & 18 & 18 & 1,29 & 1,00 \\
\hline HS36 & 7398 & 4910 & 205 & 168 & 120 & 85 & 1 & 2 & 16 & 17 & 1,53 & 1,00 \\
\hline HS37 & 7277 & 4491 & 210 & 185 & 133 & 98 & 2 & 2 & 19 & 15 & 1,16 & 0,97 \\
\hline HS38 & 6468 & 4658 & 200 & 183 & 118 & 88 & 2 & 1 & 18 & 18 & 1,14 & 0,95 \\
\hline HS39 & 5810 & 2988 & 210 & 170 & 113 & 85 & 0 & 2 & 18 & 17 & 1,23 & 1,02 \\
\hline HS40 & 7950 & 4650 & 215 & 193 & 130 & 103 & 1 & 1 & 18 & 15 & 1,58 & 1,07 \\
\hline HS41 & 6109 & 3862 & 225 & 175 & 135 & 78 & 0 & 1 & 19 & 18 & 1,22 & 0,97 \\
\hline HS42 & 7115 & 6217 & 225 & 190 & 128 & 100 & 0 & 0 & 21 & 18 & 1,42 & 1,15 \\
\hline HS43 & 3629 & 2483 & 190 & 158 & 123 & 88 & 3 & 4 & 19 & 19 & 1,03 & 0,76 \\
\hline HS44 & 8083 & 4397 & 205 & 175 & 135 & 93 & 0 & 2 & 18 & 16 & 1,44 & 1,00 \\
\hline HS45 & 6212 & 4365 & 205 & 173 & 140 & 100 & 4 & 1 & 20 & 18 & 1,29 & 1,05 \\
\hline Test. 1 & 2811 & 1477 & 133 & 118 & 78 & 55 & 0 & 1 & 13 & 12 & 0,92 & 0,68 \\
\hline $\operatorname{LSD}(5 \%)$ & 2085 & 2150 & 23 & 31 & 22 & 26 & & & 3 & 5 & 0,04 & 0,11 \\
\hline \multicolumn{13}{|l|}{ MEANS } \\
\hline Lines & 2080 & 1206 & 164 & 133 & 91 & 66 & 1 & 0 & 15 & 16 & 1,05 & 0,76 \\
\hline Crosses & 6730 & 4346 & 209 & 182 & 122 & 94 & 1 & 2 & 17 & 17 & 1,29 & 1,00 \\
\hline Test. & 2811 & 1477 & 133 & 118 & 78 & 55 & 0 & 1 & 13 & 12 & 0,92 & 0,68 \\
\hline General & $5830 \mathrm{a}$ & $3734 \mathrm{~b}$ & $199 \mathrm{a}$ & $172 \mathrm{~b}$ & $115 a$ & $88 \mathrm{~b}$ & la & la & $17 \mathrm{a}$ & $17 \mathrm{a}$ & $1,24 \mathrm{a}$ & $0,95 b$ \\
\hline
\end{tabular}

${ }^{1}$ Means followed by the same letter are not statistically different $(\mathrm{P}=0.05)$.

reduction in the photosynthesis structures components levels, e.g. chlorophyll, resulting in a reduction in the photosynthesis capacity also in carboxilase efficiency and, therefore low yielding (Delgado et al., 1994; Settini \& Maranville, 1997). Guang Jauh et al., (1995), working with maize hybrids from a 6 parent half-diallel cross pointed out that in general grain yield showed high heterosis at the higher nitrogen levels. Yield under N0 level was lowest for line L 3 and highest for line L 2, and yield under N1 level line L 4 was lowest and highest for line L 8. Differences among inbred lines and single crosses were observed for $\mathrm{PH}, \mathrm{EH}$ and Prol traits. Inbred L3 presented the lowest values under low $\mathrm{N}$ level, and there were consisting differences for the results under high level of $\mathrm{N}$, for these three traits. For the trait Prol, means of single crosses and inbred lines were greater under N1 level than for N0 level, maybe due to the reduction in $\mathrm{PH}$ and $\mathrm{EH}$. Nitrogen treatments had an important effect on the means of inbred lines under $\mathrm{N} 1$ in comparison with $\mathrm{N} 0$ resulting in a reduction of $18,9 \%(\mathrm{PH}), 27,5 \%(\mathrm{EH})$ and $27,6 \%$ (Prol). Similarly, the reduction for single crosses means were $12,9 \%, 22,9 \%$ and $22,5 \%$ for 
PH, EH and Prol, respectively. Thus, as was expected reductions in terms of average performance were lower for single crosses than for the lines. Similar results were found by Laffite et al., 1995, Kling et al., 1997; and Arellano et al. 1997. The analysis of variance for ear yield showed significant $(\mathrm{P}<0,01)$ for genotypes under N1 and N0 levels (Table 2).

TABLE 2. Summaries of the analysis of variance for ear yield $\left(\mathrm{kg} \mathrm{ha}^{-1}\right)$ for maize inbred lines and a diallel set of 45 crosses among these lines in experiments with two levels of N. EMS/ EMBRAPA,SL(MG), 2002.

\begin{tabular}{lccc}
\hline \multicolumn{1}{c}{ SV } & DF & MS & F \\
\hline Genotype & 54 & 84.856 .487 .706 & $* *$ \\
G.C.A. & 9 & 34.453 .093 .416 & $* *$ \\
S.C.A. & 44 & 94.937 .166 .564 & $* *$ \\
Error & 40 & 10.656 .020 .055 & \\
& & Low N (N0) & \\
Genotype & 54 & 42.629 .329 .923 & $* *$ \\
G.C.A. & 9 & 15.785 .081 .132 & ns \\
S.C.A. & 45 & 47.998 .179 .681 & $* *$ \\
Error & 40 & 11.333 .520 .108 & \\
\hline
\end{tabular}

$\mathrm{CV}(\mathrm{N} 1)=17,70 \% ; \mathrm{CV}(\mathrm{N} 0)=27,50 \%$

** significant at the $1 \%$ level of probability by $\mathrm{F}$ test; $\mathrm{ns}=$ Non significant

Significant $(\mathrm{P}<0,01)$ was detected for SCA under both $\mathrm{N}$ treatments, but GCA was only significant ( $\mathrm{P}<0,001)$ under N1. Arellano, et al. 1997, found significant differences for GCA and SCA effects in a study involving a diallel of 14 inbred lines, and because SCA effects for yield were larger under low $\mathrm{N}$ level, they consider that these effects were more important under low than under high $\mathrm{N}$ availability. On the other hand, Below et al. (1997) working with six temperate lines found that additive effects were more important than dominance effects. Estimates of the SCA and GCA effects for both N levels, for $\mathrm{EY}$ of the 10 inbred lines are presented in
Table 3. GCA and SCA effects differed according to the level of available nitrogen. Although the additive effects have been detected, the SCA effects predominated over the GCA. According to Baker (1978), for the non-random diallel cross model or variance, the proportion of GCA in relation to SCA can be calculated by GCA/(GCA+SCA). The value of this proportion for the trait $\mathrm{EY}$, were $26,8 \%$ and $24,7 \%$ for $\mathrm{N} 1$ and $\mathrm{N} 0$ conditions, respectively. The GCA estimated effects were positive for the lines L1, L2, L3, L6, L7 and L10, under N0 level. Under N1 level, lines L1, L2, L6, L7, L8 and L10 also presented favorable GCA effects. Therefore, five out of the ten lines present high GCA effects in both N0 and N1 levels. Lines L4, L5 and L9 had negative GCA effects at both levels of N. This led to a conclusion that the involvement of additive gene action should facilitate selection efforts for better line identification under non-stress environments. Shieh (1995) and Morarium (1994) evaluating diallel crosses and levels of nitrogen, found significant difference for GCA for the genotypes at the same N level and SCA and GCA were consistent for most of the genotypes over different $\mathrm{N}$ levels. Normally, breeders are interested in hybrid combinations, with more favorable SCA and where there is at least one of the lines with more favorable GCA effect. Therefore, crosses like L1 x L2 should be highly desirable.

Therefore, our results agree with earlier results found (Bellow et al., 1997; Laffite \& Edmeades, 1995; Rizzi et al, 1995) that show yield of inbred lines related to $\mathrm{N}$ use are under genetic control. As shown by the results of the others traits, the identification of traits related to EY at high and low $\mathrm{N}$ levels could allow the development or identification of hybrids with high performance to stress environments.

A further part of this study was the examination of the most promising lines to N efficiency. As seen in Figure 1, quadrant 1, characterized by low 


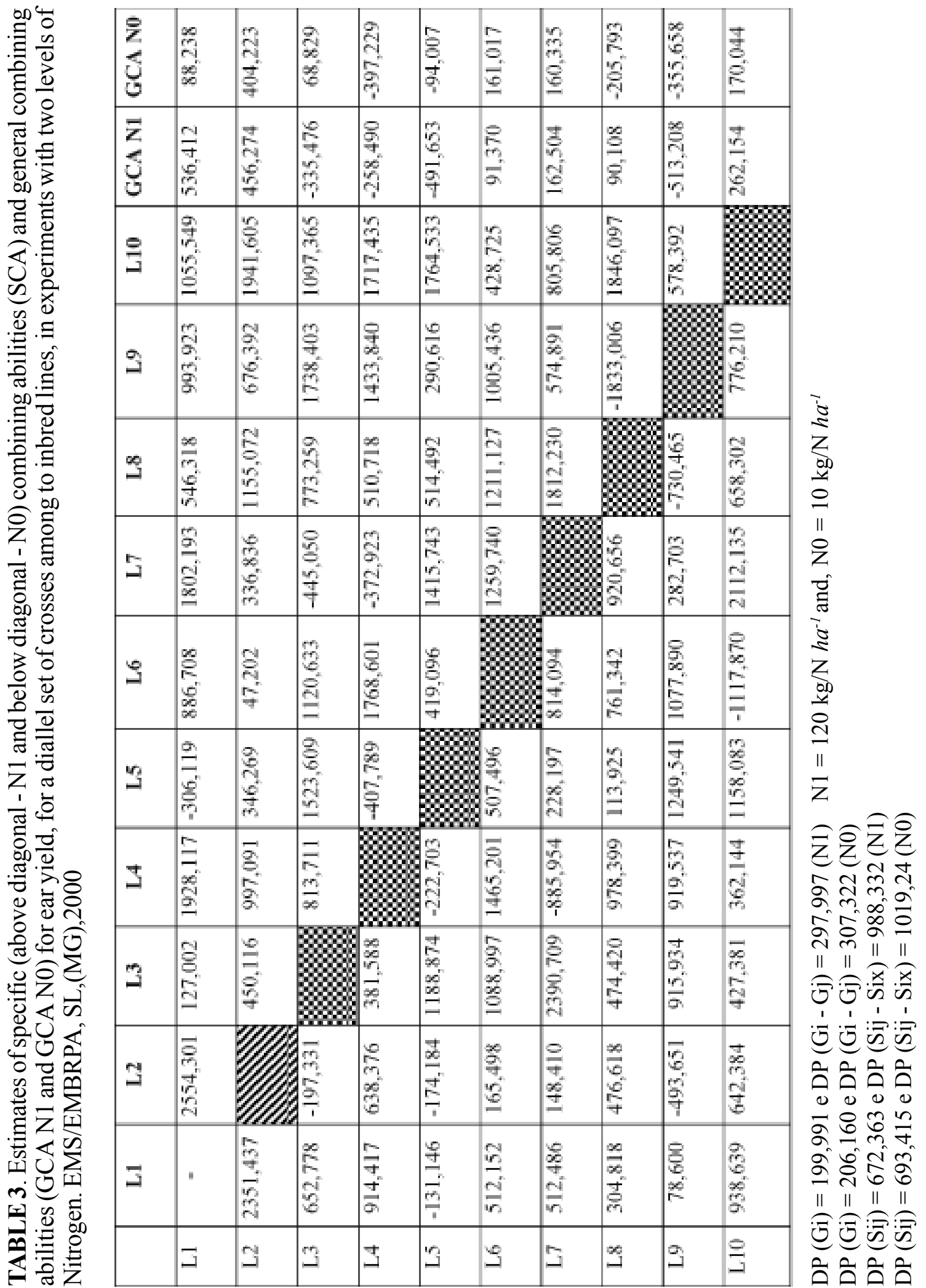




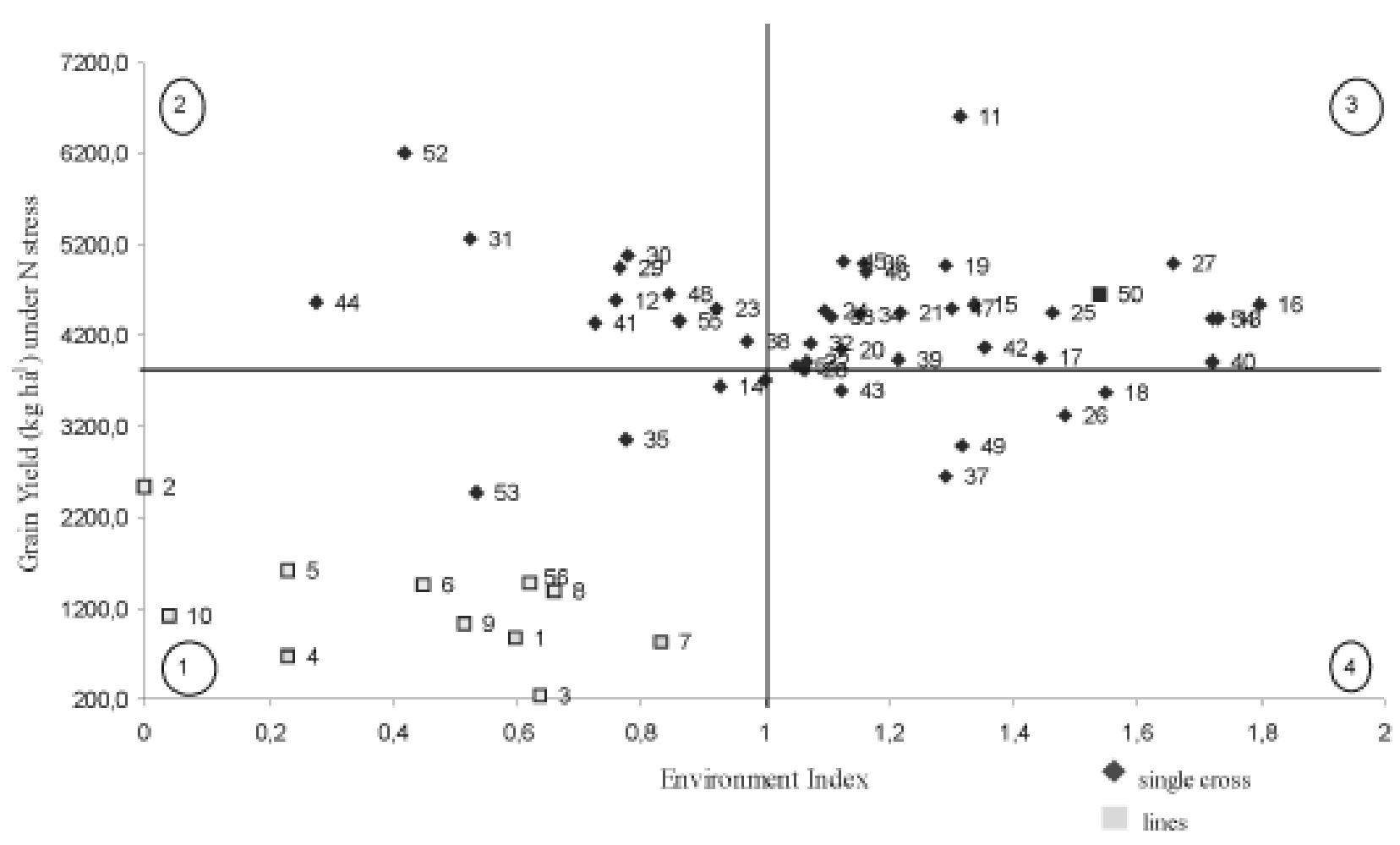

FIGURE 1. Ear yield as or function of environment index (EI) for 10 lines, 45 single crosse, and 1 line tester trials under two N levels. SL (MG), 2000.

NSI (N Stress Index) and low yield, was composed of all the lines and the inbred tester. Quadrant 3, characterized by high NSI and yield, was composed of 17 single crosses being classified as high yielding and responsive to $\mathrm{N}$ stress.

These findings are of importance to breeders who want to select more efficient genotypes to abiotic stresses such as $\mathrm{N}$ stress, which is one of the most widely stresses occurring in maize farmers' fields in the tropics.

\section{Conclusions}

The productivity of the inbred lines and the single crosses were different and were dependent on the $\mathrm{N}$ level.

Under low $\mathrm{N}$ level was observed a reduction in the traits EY, PH, EH, and Prol.

For the trait EY, non-additive gene action was predominant under both environments and additive only in the non stress environment.
The highest SCA estimates were observed in crosses between parents contrasting in magnitude and sign of GCA.

Some lines and hybrids identified in this study showed to be promising for growing under conditions of low soil nitrogen availability.

\section{References}

ANUÁRIO ESTATÍSTICO DO SETOR DE FERTILIZANTES. 2000, São Paulo: ANDA, 2001.

ARELLANO, V.J.L.; CASTILLO, F.G.; ALCANTAR, G.G.; MARTÍNEZ, A.G. Parámetros Genéticos de la Eficiencia en el Uso de Nitrógeno en Líneas de Maíz de Valles Altos. In: EDMEADES, G.O.; BÄNZIGER, M.; MICKELSON, H.R.; PENAVALDIVIA, C.B. (Ed.). In: SYMPOSIUM. DEVELOPING DROUGHT AND LOW NTOLERANT MAIZE, 1996, El Batan: Proceedings...El Batan: CIMMYT, 1997. P.320-325. 
BAKER, R.J. Issues in diallel analysis. Crop Science, Madison. v.18, p.533-536, 1978.

BALKO, L.G.; RUSSELL, W.A. Effects of rates of nitrogen fertilizer on maize inbred lines and hybrid progeny. I. Prediction of yield responses. Maydica, Bergamo. v.25, p. 65-79,1980.

BÄNZIGER, M; LAFITTE, H.R. Efficiency of secondary traits for improving maize for low-nitrogen target environments. Crop Science, Madison, v.37, p.1110-1117, 1997.

BELOW, F.E.; BRANDAU, P.S.; LAMBERT, R.J.; TEYKER, R.H. 1997. Combining Ability for Nitrogen Use in Maize. In: EDMEADE, G.O.; BÄNZIGER, M.; MICKELSON, H.R.; PENAVALDIVIA, C.B. (Ed.). In: SYMPOSIUM DEVELOPING DROUGHT AND LOW NTOLERANT MAIZE, 1996, El Batan. Proceedings... El Batán: CIMMYT, 1997. p.316319.

CLARK, R.B.; DUNCAN, R.R. Improvement of plant mineral nutrition through breeding. Field Crops Researchi, Amsterdan, v. 27, p.219-240, 1991.

DELGADO, E.; MITCHELL, R.A.C.; PARRY, M. A.; DRISCOLL, S. P.; MITCHELL, V.J.; LAWLOR, D.W. Interacting effects of $\mathrm{CO} 2$ concentration, temperature and nitrogen supply on the photosynthesis and composition of winter wheat leaves. Plant Physiology, Bethesda, v.138, n.29, p.1193-200, 1994.

GRIFFING, B. Concept of general and specific combining ability in relation to diallel crossing systems. Australian Journal Biological. Sciences, Melborne, v.9, p.463-493, 1956.

KLING, J.G., OIKEN, S.O.; AKINTOEY, H.A.; HEUBERGER, H.T.; HORST, W.J. Potential for Developing Nitrogen Use Efficient Maize for
Low Input Agricultural Systems in the Moist Savannas of Africa. In: EDMEADES, G.O.; BÄNZIGER, M.; MICKELSON, H.R.; PENAVALDIVIA, C.B. (Ed.). In: SYMPOSIUM DEVELOPING DROUGHT AND LOW NTOLERANT MAIZE, 1996, El Batan, Proceedings...El Batan: CIMMYT, 1997. p.490501.

LAFITTE, H.R.; EDMEADES, G.O. Association between traits in tropical maize inbred lines and their hybrids under high and low soil nitrogen. Maydica, Bergamo, v.40, p. 259-267, 1995.

LAFITTE, H.R.; BÄNZIGER, M. 1996. Maize population improvement for low soil Nitrogen: Selection gains and the identification of secondary traits. In: EDMEADES, G.O.; BÄNZIGER, M.; MICKELSON, H.R.; PENAVALDIVIA, C.B. (Ed.). In: SYMPOSIUM DEVELOPING DROUGHT AND LOW NTOLERANT MAIZE, 1996, El Batan, Proceedings...El Batan: CIMMYT, 1997. p.485489.

MERCADO brasileiro de fertilizantes: consumo de fertilizantes por cultura no Brasil. Anuário Estatítico Setor de Fertilidades 2000, São Paulo, p.33, 2001.

MOLL, R.H.; KAMPRATH, E.L.; JACKSON, W.A. Analysis and interpretation of factors which contribute to efficiency of nitrogen utilization. Agronomy Journal, Madison, v.74, p.562-564, 1982.

MORARIUM-M. Genetic effects implied in the determination of maize reaction to crop intensification factors- mineral $\mathrm{N}$ fertilization and plant population. Romanian Agricultural Research. n.2, p. 7-1, 1994.

MUCHOW, R.C.; SINCLAIR, T.R. Nitrogen response of leaf photosynthesis and canopy radiation 
use efficiency in field grown maize and sorghum. Crop Science, Madison, v.34, p.721-723, 1994.

MURULI, B.L.; PAUSEN, G.M. Improvement of nitrogen use efficiency and its relationship to others traits in maize. Maydica, Bergamo, v.26, p.63-73, 1981.

PAN, W.L.; JACKSON, W.A.; MOLL, R.H. Nitrate uptake and partitioning by corn (Zea mays L.) root systems and associated morphological differences among genotypes and stages of root development. Journal of Experimental Botany, London, v.36, p.1341-1351, 1985.

POLLMER, W.G.; EBERHARD, D; KLEIN, D.; DHILLON, B.S. Genetic control of nitrogen uptake and translocation in maize. Crop Science, Madison, v.19, p. 83-86, 1979.

RIZZI, E.; BALCONI, C.; MENBRINI, L.; STEFANINI, F.M.; COPOLLINO, F.; MOTTO, $\mathrm{M}$. Genetic variation and relationship among Nrelated traits in maize. Maydica, Bergamo, v.38, p.23-30, 1993.
SETTINI, J.R; MARANVILLE, J.W. Carbon dioxide assimilation efficiency of maize leaves under nitrogen stress at different stages of plant development. Communication Soil Science and Plant Analysis, New York, v.29, n.7-8, p.777-792. 1998.

SHIEH, G.; HO, C.; LU, H. The effect of nitrogen rate on the combining ability and heterosis in maize traits. Journal of Agricultural Research of China, Taiwan, v.44, n.1, p. 15-25. 1995.

TA, C.T.; WIELAND, R.T. Nitrogen partitioning in maize during ear development. Crop Science, Madison, v.32, p.443-451, 1992.

WONG, S.; COWAN, I.R.; FARQUHAR, G.D. Leaf conductance in relation to rate of $\mathrm{CO}_{2}$ assimilation 1. Influence of $\mathrm{N}$ nutrition, phosphorus nutrition and flux density and ambient partial pressure of $\mathrm{CO}_{2}$ during antogeny. Plant Physiology, Bethesda, v.78, p. 821-825, 1984. 